\title{
A felszíni vizek monitoringjának hazai és európai uniós operatív rendszere
}

\section{The Operational System of Surface Water Monitoring in Hungary and the European Union}

\begin{abstract}
A szerző célja egy átfogó kép nyújtása a fenntartható és integrált vízgazdálkodás többek között vízminőségvédelmi vonatkozásában is müködtetett felszíni megfigyelö hazai és nemzetközi rendszerekröl. A hazai és nemzetközi történeti bevezető után a cikk a Víz Keretirányelv és az ennek megfigyelésére müködtetett hazai és európai uniós rendszerek történeti, vízdiplomáciai hátteréröl, felépitéséröl, operatív müködéséröl ad információt. A 40 év vízminőségvédelmi törekvéseinek érdekében született egyezmények és intézményi összefogások eredményei, a megfigyelő hálózatok felépitése, egymást támogató rendszere hasznos alaptudást biztosít például az éghajlatváltozásra, a biodiverzitás-csökkenésre és a társadalmi, mezögazdasági igényekre reagáló, új intézkedéseket tervező szakemberek számára az intézkedések hatásvizsgálatának alapját képező monitoringfelállitással kapcsolatban.
\end{abstract}

Kulcsszavak: vízminőség-védelem, monitoringrendszer, Víz Keretirányelv, Duna védelme

The aim of the author is to provide a comprehensive picture of the national and international surface monitoring systems operated in the field of water quality protection between sustainable and integrated water management. After the national and international historical introduction, the article provides information on the historical, water diplomatic background and structure of the Water Framework Directive and its operated monitoring system. Studying the results of conventions and institutional collaborations for the 40 years of water quality protection, the structure of monitoring networks, and the mutually supportive system, provides a useful basic knowledge for water experts who design new measures in response to climate change, biodiversity loss and social

Országos Vízügyi Főigazgatóság, projektkoordinátor, Nemzeti Közszolgálati Egyetem Hadtudományi és Honvédtisztképző Kar Katonai Műszaki Doktori Iskola, doktori hallgató, e-mail: lakatosboglarka@uni-nke.hu, ORCID: https://orcid.org/0000-0001-7760-3190 
and agricultural needs in connection with setting up monitoring as a basis for impact assessment of measures.

Keywords: water quality protection, monitoring system, Water Framework Directive, protection of the Danube

\section{Bevezetés}

A nemzeti vízkincs mennyiségi és minőségi védelme nemzetbiztonsági érdek. A mennyiségi és minőségi elemek nem szétválaszthatók, így azok megfigyelése és védelme közös gondolkodást kíván mérnöktöl és ökológustól, biológusoktól, kémikusoktól. ${ }^{2}$ Globális probléma a szenynyezett vagy épp a nem megfelelő mennyisége miatt már öntisztulásra képtelen víz. Ezt hivatott támogatni a felszíni vizek minőségének monitoringrendszere, amelyet valamilyen szinten már minden ország végez, az európai uniósok, vagyis hazánk is szigorú feltételeknek tesz eleget. A vízminőség-védelem nem egyszerűen az eredeti állapot megőrzését és megvédését jelenti. Az európai irányok ökológiai szemlélettel teremtenek összhangot a természet- és környezetvédelmi, valamint a gazdasági érdekek között, a vizek jó állapotának megőrzése érdekében.

Az Európai Víz Keretirányelv szerint, amely nevéből adódóan mintegy iránymutatást ad a holisztikus és ökológiai szemléletű vízgazdálkodási, egyben környezet- és természetvédelmi tevékenységek számára, alapvető feladat a vízminőség fejlesztése, legalább a jó állapot eléréséig. Ez természetesen nemcsak a szűk értelemben vett vízterekre-víztestekre vonatkozik, hanem az egész vízgyűjtő területre, hiszen annak természeti és antropogén adottságai határozzák meg az ottani vizek minőségét.

A Bizottság 2012-ben tette közzé a Víz Keretirányelv harmadik végrehajtási jelentését. Ebben azt állapította meg, hogy a felszíni víztestek 43\%-a volt jó állapotban 2009-ben, ez a szám pedig 2015-re várhatóan 53\%-ra fog emelkedni a tagállamok tervezett intézkedései révén. Következésképpen további intézkedések hiányában 2015-re a célkitűzésektől való 47\%-os elmaradás várható. ${ }^{3}$ A vízkészletek megörzésére irányuló EU-terv meghatározza, hogy mely az előrelépést gátló akadályokat kell leküzdeni, és a jobb végrehajtásra, a politikai célkitűzések fokozottabb integrációjára és a fennmaradó szabályozási hiányosságok felszámolására összpontosít. Olyan főbb témákat határoz meg, mint például a földhasználat, a vízszennyezés, a vízfelhasználás hatékonysága és rugalmassága, továbbá a jobb irányítás.

Annak érdekében, hogy láthassuk a vízminőség hatékony védelmének alapjául szolgáló megfigyelési rendszerek müködését és hatásfokát, a következő fejezetekben a Magyarországon és az Európai Unió keretirányelvének iránymutatása alapján müködő nemzetközi megfigyelő rendszerek felépítését mutatom be.

Somlyódy László: Vízminőségi modellek és a mérnök. Hidrológiai Közlöny, 98. (2018), 2. 13-22.

A bizottság jelentése az Európai Parlamentnek és a Tanácsnak a víz-keretirányelv (2000/60/EK) és az árvízvédelmi irányelv (2007/60/EK) végrehajtásáról. Második vízgyűjtő-gazdálkodási tervek. Első árvízkockázat-kezelési tervek. Brüsszel, 2019. 


\section{Hazai vízminőség-vizsgálatok történeti áttekintése}

1823-ban kezdődtek az első vízállás-megfigyelések a Dunán, a Tiszán pedig 1833-ban. A kémiai vízminőség-megfigyelések ezzel szemben a vegytannal együtt fejlődtek. A 20. század első felében elszórtan, kampányszerüen vizsgálták egy-egy nagyobb folyó vízminőségét.

A rendszeres vízminőségi monitoring a Vízgazdálkodási Tudományos Kutatóintézet (VITUKI) 1952-es megalakulásához és az intézet Vízminőségi Osztályához kapcsolódik. Az 1950-es években a VITUKI mintegy 130 vízfolyás 1400 szelvényében 25 vízminőségi komponens értékét rögzítette évi gyakorisággal, és ezzel párhuzamosan kidolgozta az úgynevezett KGST-módszert. ${ }^{4}$ A KGST-módszer szerinti vízminősítés alapjául az úgynevezett vízminőségi normatívák - a víz összetételének és tulajdonságainak jellemzésére szolgáló mutatószámok határértékei - szolgáltak. A vízminőségi normatívák alapján történő minősítést elsősorban a vízfelhasználók igényei határozták meg. A KGST-módszer 5 alapján a felszíni vizeket az I-IV. (tiszta / kissé szennyezett / szennyezett / osztályon kívüli, nagyon szennyezett, szennyvíz) vízminőségi osztályba sorolták. Három csoportot mért. Az oxigénforgalom mutatói: oldott oxigén, oxigéntelítettség, biokémiai oxigénigény, kémiai oxigénfogyasztás, kénhidrogén-tartalom, szaprobiológiai állapot. Az ásványi anyag tartalom mutatói: klorid, szulfát, összes keménység, kalcium, magnézium, száraz maradék. És a különleges mutatók: ammónium, nitrát, fenolok, szintetikus mosószerek, $\mathrm{pH}$, összes vas, mangán, hőmérséklet, szag és íz, szín, olaj, Coli-érték; cianidok, kórokozó csírák, káros anyagok (ólom, arzén, higany, réz, cink, kadmium, króm-III, króm-VI, kobalt, ezüst, szulfidionok, vanádium, bór). ${ }^{6}$

A KGST-módszert 1983-ig használták, amikor is az MSZ 10-172/1-83 szabvány bevezetésével áttértek az integrált minősítési rendszer alkalmazására. Az integrált minősítés alapja az volt, hogy a felszíni vizeknek biztosítani kellett a vízi ökoszisztémák viszonylagos stabilitását, és egyidejüleg ki kellett elégítenie a vízhasználatok igényeit is. A VKI feltáró monitoringra leginkább hasonlító programban a víz típusától függően havi, kétheti (néhol kéthavi vagy heti) gyakorisággal vizsgálták a felszíni vizeket. Ez a hálózat tehát a jelentősebb vízfolyásokat és állóvizeket fedte le, és nemzetközi összehasonlításban is jónak volt mondható: mintegy 150 törzshálózati, 90 regionális, több száz lokális mintavételi helyen történtek a mintavételek. Az adatellenőrzést követően a VITUKI-ban évente elkészítették az ország vízminőségi térképét, amelyen a nagyobb vízfolyásokat ábrázolták.

A monitoringrendszer tehát folyamatos és szisztematikus fejlődésen ment keresztül az 1950-es évektől kezdve, ami mint később látni fogjuk, Magyarország előrehaladottságát jelöli legalábbis vízminőségmérési szempontból. Folyamatosan nőtt a mérési helyszínek, a mintavételek és többé-kevésbé a mérések száma is. A mérési helyszíneket illetően ugyanak-

4 Clement Adrienne - Somlyódy László: Vízminőség és szabályozása. In Somlyódy László (szerk.): A hazai vízgazdálkodás stratégiai kérdései. Budapest, Magyar Tudományos Akadémia, 2002.

5 A Kölcsönös Gazdasági Segítség Tanácsa (rövidítve KGST, angolul Comecon) a közép-és kelet-európai szocialista országok gazdasági együttműködési szervezete volt a hidegháború alatt 1949 és 1991 között.

6 Szabó Attila Péter: Háttérváltozók szerepe a Duna és a Tisza ökológiai minősítésében. Doktori értekezés. Debreceni Egyetem, 2008. 
kor messze alulreprezentáltak voltak a kis (1000 km²-nél kisebb vízgyüjtő területü, 1 m³/s-nál kisebb középvízhozamú) vízfolyások. ${ }^{7}$

\section{Európa vízminőségi mérföldkövei}

Az Európai Környezetvédelmi Ügynökség (EEA) 1998-as jelentése szerint az európai vizek általános szintje az 1980-as évek óta nem javult jelentősen, föleg a felszín alatti vizek és a kisebb vízfolyások vannak veszélyben. 2003-ban megjelent a Vizek állapota Európában címü összefoglaló dokumentum, amely szerint az előző évekhez képest a vizek védelme és minősége javuló tendenciát mutat (EEA 2003). ${ }^{8}$ Az EEA készített egy Környezet az Európai Unióban-1995 címü tanulmányt, amely rávilágított a Közösség vizeinek mennyiségi és minőségi védelmét célzó intézkedések szükségességére, többek között ez és az 1991-es hágai miniszteri szeminárium is elősegítette az édesvizek hosszú távú minőségi és mennyiségi leromlásának megakadályozására egy 2000-ig kidolgozandó cselekvési programról szóló nyilatkozat megalkotását.

Az Európai Unió új vízgazdálkodási politikáját Franciaország, Hollandia, Nagy-Britannia, Németország és Portugália szakértőcsoportja által kidolgozott EUROWATER projekt alapozta meg. Az említett projekt alapján végzett elemzés - amely már tartalmazta az EU-s tapasztalatokat és módszertanokat - bebizonyította, hogy az elkészült anyag alkalmas az EU harmonizációs előkészítésére.

\subsection{További együttmüködések a Duna védelmében}

Európában a közös gondolkodás indulása az 1980-as évekre tehető. Itt kezdődtek meg először a Duna vízgyűjtőjének védelmében létrehozott közös érdekeltségü területek mint prioritások. A Danube Rectors' Conference: Dunai Rektorok Konferenciáját az ulmi, linzi, bécsi és budapesti egyetemek rektorai 1983-ban alapították meg egy bécsi találkozó alkalmával. Azóta számos más intézmény is csatlakozott a kezdeményezéshez, 60 egyetem jelenleg a tagja, köztük az Andrássy Egyetem, a Corvinus, az ELTE, a Semmelweis és a Pécsi Egyetem. ${ }^{9}$

A Duna Védelmi Egyezményről és a Duna Védelmi Nemzetközi Bizottságról - International Commission for the Protection of the Danube River (ICPDR $)^{10}$ szóló egyezményt 1994. június 29-én írták alá Szófiában. A dokumentum kialakította azt az átfogó jogi eszközt, amely biztosítja a határokon átnyúló vízgazdálkodási együttmüködést a Duna-medencében. Az egyezmény 1998-ban lépett hatályba. Célja a Duna-medence felszíni és felszín alatti vizeinek fenntartható és egyenlőségen alapuló kezelésének és használatának biztosítása.

Az egyezményt 11 Duna menti állam - Ausztria, Bulgária, Horvátország, Cseh Köztársaság, Németország, Magyarország, Moldova, Románia, Szlovákia, Szlovénia és Ukrajna -, valamint az Európai Közösség írta alá. Az aláírók 1998-ban létrehozták a Duna Védelmi Nemzetközi

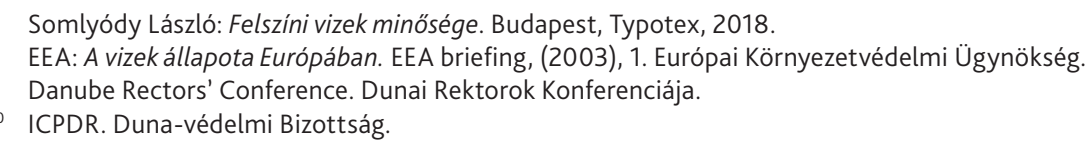


Bizottságot (ICPDR). A fő célja a Duna Védelmi Egyezmény végrehajtásának támogatása volt. 2000-ben az aláírók ugyanakkor a Víz Keretirányelv végrehajtását koordináló Duna-vízgyűjtőkerület szintű nemzetközi testületté nyilvánították, amely a VKI-ból származó nemzetközi jelentőségű kérdéseknek és feladatoknak egyeztetéséhez kínál szervezetet. A Bizottság célja a Duna-víz mennyiségi és minőségi védelme. Az ICPDR tagjai nemzeti küldöttek, minisztériumok képviselői, műszaki szakértők és civil szervezetek képviselői, valamint tudományos kutatók.

\subsection{Az Európai Közösség Víz Keretirányelve}

Az Európai Közösség az 1970-es évektől egyre több olyan jogszabályt léptetett hatályba, amely a vizek védelmét szolgálta, viszont a vizek állapota nem javult. Ezért az 1990-es évek közepére kidolgozták az EU új Víz Politikáját, amelynek végrehajtására fogadták el a Víz Keretirányelvet, amely 2000. december 22-én lépett hatályba. A keretirányelv végrehajtásának fö célja, hogy 2015 végéig, az EU tagállamaiban jó állapotba kerüljön minden olyan felszíni és felszín alatti víz, amelynek jó állapotba hozásához, illetve jó állapotának megőrzéséhez szükséges intézkedések szakmai szempontból megvalósíthatók, nem sértik súlyosan a közérdeket, és nem elviselhetetlenül költségesek a társadalom számára.

A Víz Keretirányelv megteremti a jogi kereteket a szárazföldi felszíni vizek, az átmeneti vizek, a parti vizek és a felszín alatti vizek védelmének megvalósításához. Az általános célokat az 1. cikk határozza meg:

- A vízi ökoszisztémák és - tekintettel azok vízszükségletére - a vízi ökoszisztémáktól közvetlenül függő szárazföldi ökoszisztémák és vizes élőhelyek állapotának javítása és védelme.

- A vízkészletek fenntartható használatának elősegítése.

- A különösen veszélyes anyagok vizekbe való bevezetésének fokozatos csökkentése és megszüntetése.

- A felszín alatti vizek szennyezésének csökkentése.

- Az áradások és aszályok hatásainak mérséklése.

A célkitüzések elérése érdekében minden tagállamnak fel kell mérnie vizeinek jelenlegi állapotát, stratégiát kell készítenie a meghatározott célok elérése érdekében. Ehhez vízgyűjtő egységeket kellett meghatároznia, amelyekre vízgyűjtőgazdálkodási terveket dolgoztak/dolgoznak ki, amelyeket hatévente meg kell újítani. Ezek a tervek a vízügyi és környezetvédelmi feladatokon túl társadalmi-gazdasági hatásokat, kapcsolatokat is elemeznek. A terveknek az alábbi elemzéseket kell tartalmazniuk:

- a vízgyűjtő általános leírását, beleértve a felszín alatti vizeket is;

- minden jelentősebb terhelés és emberi tevékenység vizekre való hatásainak összefoglalását;

- a védett területek és a megfigyelési hálózat leírását;

- a vizekre vonatkozó környezeti célkitűzések listáját;

- a gazdasági elemzés, valamint

- minden intézkedés és intézkedési program összefoglalását;

- az illetékes hatóságok felsorolását, továbbá 
- a tájékoztatásra tett intézkedések és a vízgyüjtőgazdálkodási terv készítése során végzett társadalombevonási tevékenység összefoglalását.

A vízgyűjtők jelentős része több állam területére esik. A tagállamok által tervezett vízgyűjtőterületek 30\%-a nemzetközi, és ezek a tagállamok területének 66\%-án terülnek el. A nemzetközi vízgyűjtők kezelésére, a nemzetközi vízgyüjtőgazdálkodási terv módszertanának kifejlesztésére indult el az EU MANTRA-EAST Projekt. ${ }^{11}$

\section{A VKI végrehajtása Európában}

Az Európai Unió Vízügyi Igazgatói Értekezletének támogatásával és koordinálásával EU-szintű közös stratégiát (CIS) dolgoztak ki a Víz Keretirányelv végrehajtásához. A közös stratégia célkitủzése és programja a Keretirányelv végrehajtásának a módszertani előkészítését és a végrehajtáshoz szükséges módszertani útmutatók kidolgozását szolgálja. Az első ábrán a végrehajtáshoz szükséges fö elemeket és az általános módszerének kulcstevékenységeit láthatjuk. ${ }^{12}$

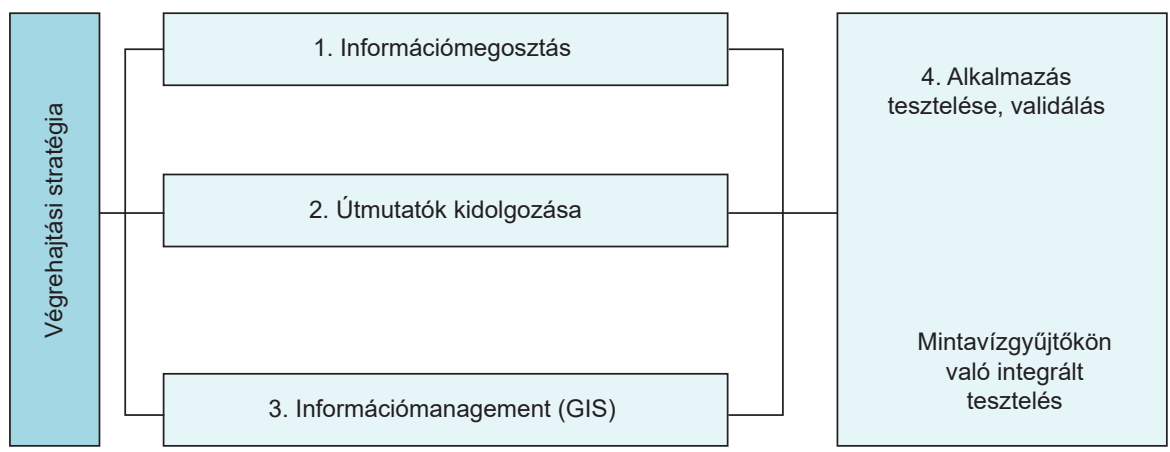

1. ábra. A Víz Keretirányelv végrehajtásának moduláris szerkezete

Forrás: Nagy Zsuzsanna szerkesztése a Common Implementation Strategy for the Water Framework Directive (2000/60/EC). Luxembourg, Office for Official Publications of the European Communities, 2009. alapján

A végrehajtási stratégia három alapeleme végig kapcsolódik az alkalmazás tesztelésére és validálására irányuló tevékenységek figyelemmel kísérésére és az eredményeik beépítésére. A különböző munkacsoportok munkáinak koordinálására, eredményeinek értékelésére Stratégiai Koordináló Csoportot hoztak létre, amely többek között a vízügyi igazgatók értekezletére előkészíti a dokumentumokat, és útmutatókat ad a kulcstevékenységekhez, valamint felhatalmazással rendelkezik a stratégiai dokumentum továbbfejlesztésére. Mindezek eredményeképpen

Hardi Tamás: Duna-stratégia és területi fejlödés. Digitális kiadás. Budapest, Akadémiai Kiadó, 2016.

12 Nagy Zsuzsanna: A biológiai elemek állapotát befolyásoló főbb hidromorfológiai tényezők meghatározása magyarországi kisvízfolyásokra. Doktori értekezés. Budapest, Corvinus Egyetem, Kertészettudományi Doktori Iskola, 2007. 15. 
2006 nyarára elkészültek a közös végrehajtást segítő dokumentumok, ezeket a CIRCA- ${ }^{13}$ (EU közösségi információs) rendszerben tették elérhetővé.

Az útmutatók tesztelésére 15 minta-vízgyűjtőterületet jelöltek ki Európában (2. ábra). Közöttük szerepelnek csak egy országot (például Tevere: Olaszország) és több államot is érintő vízgyűjtők (például Sheldt: Belgium, Franciaország, Hollandia; Szamos: Magyarország, Románia).
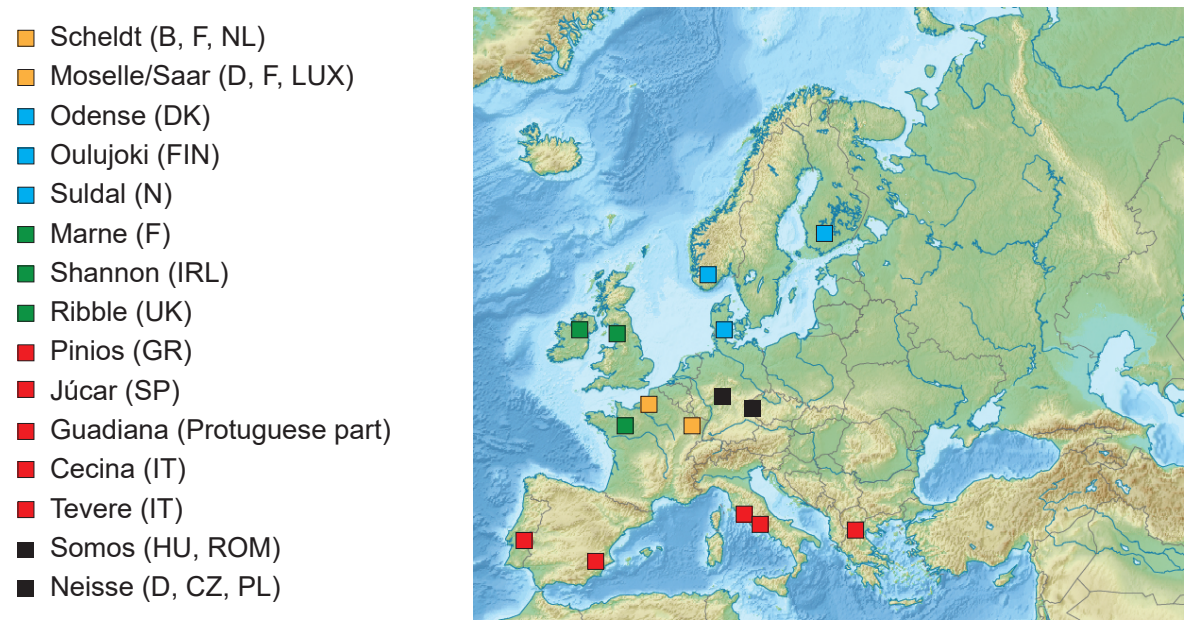

2. ábra. A kísérleti vízgyűjtők hálózata az integrált teszteléshez

Forrás: A Víz Keretirányelv Közös Végrehajtási Stratégiája: WFD Common Implementation Strategy - Progress and Work Programme 2003/2004.

\subsection{A VKI végrehajtása Magyarországon}

Az Európai Unióhoz való csatlakozásunk óta Magyarországra nézve is kötelező az ebben előírt feladatok végrehajtása, ugyanakkor az ország elhelyezkedése miatt alapvetően érdekeltek vagyunk abban is, hogy a nemzetközi Duna vízgyüjtőkerületben mielőbb teljesüljenek a VKI célkitűzései. Magyarország a VKI és a kapcsolódó irányelvek, rendeletek előírásait átültette a hazai vízgazdálkodási, vízvédelmi szabályozásba. A Víz Keretirányelv célja, hogy a felszíni és felszín alatti vizek, valamint a vizekkel kapcsolatban lévő védett területek „jó állapotba” kerüljenek. A kitüzött cél, vagyis a vízfolyások, állóvizek, felszín alatti vizek jó ökológiai, vízminőségi és mennyiségi állapotának elérése összetett és hosszú folyamat. E célok eléréséhez szükséges intézkedéseket a vízgyűjtőgazdálkodási terv foglalja össze, amely a VKI által meghatározott stratégiai tervezési módszerrel és ütemezésben, gondos és kiterjedt tervezési folyamat eredményeként születhet meg. A Kormány az 1042/2012. (II. 23.) Korm. határozattal hirdette ki Magyarország első vízgyűjtőgazdálkodási tervét (VGT1), amely a 2010-2015 közötti időszak intézkedési programját tartalmazza. 2015. évben megtörtént a VGT1 felülvizsgálata, a felülvizs-

13 A gyorsabb információcsere előmozdítása és a számos szakértői csoport munkájának megkönnyítésére a Bizottság létrehozott egy CIRCA nevü internetes platformot, amely azóta frissült a CIRCABC nevű platformra. 
gált terv (VGT2) a 2016-2021 közötti hat év cselekvési programja. A VKI 2015. december 22-re tűzi ki a jó vízállapotok elérését, amely alól indoklással 2021-ig vagy 2027-ig, vagy tartósan lehet mentességet alkalmazni. ${ }^{14}$

\section{A Duna védelme, monitoringja}

A Keretirányelv végrehajtásának előkészítéséhez 2001-ben a feljebb már említett szakértő csoport jött létre, és megkezdte a végrehajtás stratégiájának és részletes munkaprogramjának kidolgozását a Nemzetközi Duna-védelmi Bizottság (International Cooperation for the Protection of the Danube River - ICPDR).

Az ICPDR feladatai a koordináció, az információcsere, a stratégiák kidolgozása a vízgyűjtőgazdálkodási tervezéshez, a szintetizáló (roof) jelentés készítése az EU felé, illetve a módszerek és mechanizmusok harmonizálása.

A Keretirányelv előírásai szerint a vízgyűjtőgazdálkodási tervezés legfontosabb területi egysége az egész Duna-vízgyűjtő. Annak egyes részterületeire, a Duna mellékfolyóira kell az egyes államoknak részvízgyűjtőgazdálkodási terveket készíteniük, amely így hat a környezetére, és a vízgyűjtő ökoszisztémájának javulását szolgálja.

A vízgyűjtőgazdálkodási tervek készítéséhez Magyarország területét 42 tervezési alegységre osztották fel, s ezekre az illetékes vízügyi igazgatóságok vízgyűjtőgazdálkodási terveket készítettek. Magyarországon 2010-ig elkészült az országos vízgyűjtőgazdálkodási terv, valamint a Duna, a Tisza, a Dráva és a Balaton részvízgyűjtőgazdálkodási terve.

A minősítési módszerek kidolgozottságát tekintve a feladatokat formálisan teljesítettük, a típusspecifikus minősítő rendszerek elkészültek mindegyik élőlénycsoportra, illetve a háttér(fizikai-kémiai) komponensekre. Az Unió az adatok összevethetősége érdekében megkövetelte, hogy 2011-ig ezek a módszerek „interkalibráltak” legyenek, azaz egyazon vízállapot vizsgálata az országonként eltérő biológiai módszertan és értékelési rendszer ellenére egymással összevethető eredményre vezessen. ${ }^{15}$

\subsection{A Duna-védelmi Bizottság (ICPDR) monitoringrendszerének legföbb elemei}

Az ICPDR műveleteit két csoport irányítja: a rendszeresen tanácskozó munkacsoport, amely meghatározza a politikát és stratégiát, míg a felállított különleges munkacsoport útmutatási keretet biztosít, és előkészít kulcsfontosságú döntéseket. Emellett szakértők munkacsoportja és érdekképviseleti résztvevők alkotják a tudományos és technikai területeken dolgozó ülések résztvevőit. Az ICPDR nyolc szakértői csoportja (Expert Group) a struktúra létfontosságú részét képezi. Megfelelnek a Duna-védelmi egyezmény által meghatározott különféle követelményeknek, a Víz Keretirányelvnek (WFD) és az árvizekről szóló irányelvnek (Flood Directive).

14 A Duna-vízgyüjtő magyarországi része. Vizgyüjtő-gazdálkodási Terv-2015. Országos Vízügyi Főigazgatóság, 2016.

15 A Duna-vízgyüjtő magyarországi része. Vízgyüjtö-gazdálkodási Terv-2015. (2016) i. m. 4. 
A szakértői csoportok:

1. Vízgyűjtő-gazdálkodási szakértői csoport (River Basin Management Expert Group)

2. Monitoring és Értékelési Szakértői Csoport (Monitoring and Assessment Expert Group)

3. Nyomás- és mérési szakértői csoport (Pressures and Measures Expert Group)

4. Árvízvédelmi szakértői csoport (Flood Prevention Expert Group)

5. Baleset-megelőzési és -ellenőrzési szakértői csoport (Accident Prevention Control Expert Group)

6. Információkezelési és térinformatikai szakértői csoport (Information Management and GIS Expert Group)

7. Nyilvános részvételi szakértői csoport (Public Participation Expert Group)

8. Stratégiai Szakértői Csoport (Strategic Expert Group)

A nyilvánosság aktív részvétele az egyik legfontosabb kritérium a fenntartható vízgazdálkodás terén. Több mint 20 szervezet rendszeresen él is ezzel a lehetőséggel.

\subsection{A Nemzetközi Monitoringhálózat (TransNational Monitoring Network-TNMN)}

Célja egy átfogó kép nyújtása a szennyezésekről és a vízminőség hosszú távú állapotáról, illetve a Duna-medence föbb szennyezőanyag-terheléséről. Az adatok gyüjtése egységes formában történik, így azok könnyen összehasonlíthatók. Az analitikai módszerek a TNMN kritériumainak megfeleltetése esetén alapvetően szabadon választhatók.

Mind az EU VKI, mind a felülvizsgált Duna-védelmi Egyezmény követelményeinek való megfelelés érdekében a felszíni vizekre vonatkozó TNMN a következő elemekből áll:

- Felügyeleti monitoring I.: A felszíni vizek állapotának figyelemmel kísérése

- Felügyeleti monitoring II.: A specifikus nyomások figyelemmel kísérése

- Operatív monitorozás

- Vizsgálati monitoring

A felügyeleti monitoring I. a veszélyes anyagok megfigyelése. Az ICPDR szervezetében részt vevő államok egy közös megfigyelési tevékenysége, amely éves adatokat eredményez a szennyező anyagok koncentrációjáról a Duna erre kiválasztott szakaszain.

A felügyeleti monitoring II. és az operatív monitorozás a státuszra vonatkozó adatok öszszegyüjtésén alapul a vízgyűjtő felszíni és felszín alatti víztesteiről. Ennek eredményei jelennek meg hatévente a részt vevő országok Vízgyűjtő Gazdálkodási Terveiben, amely a VKI előírása.

A vizsgálati monitoring elsősorban nemzeti feladat, de a Közös Duna felmérés vízgyűjtő koncepciója megköveteli a meglévő megfigyelési módszerek harmonizálását, pótolva a VGT-ben müködő megfigyelö hálózatok információs hiányosságait. Ezenkívül új módszerek kidolgozását vagy az „új” vegyi anyagok hatásának ellenőrzését is elősegíti.

A TNMN adatgyüjtési eljárása országos szinten szerveződik. A nemzeti adatkezelők (National Data Manager - NDM) felelősek a TNMN laboratóriumaiból történő adatgyűjtésért, valamint az adatok ellenőrzéséért. A konvertálás egy korábban egyeztetett adatcsere fájlformátumban 
történik (DEFF). A menedzsmentközpont a pozsonyi Szlovák Hidrometeorológiai Intézetben székel. Ez a központ elvégzi az adatok másodlagos ellenőrzését és feltöltését a központi TNMN adatbázisába. Végül az ICPDR titkársága a TNMN-adatokat feltölti az ICPDR weboldalára. A nemzeti laboratóriumok eredményeit a Monitoringhálózat éves jelentésben teszi közzé. Ez magában foglalja a mintavételi helyeket, mérési paraméterek listáját és a mérési eredmények feldolgozásának módszertanát is. A vizsgálati monitoring alapvetően minden részt vevő ország saját feladata, de a vízgyűjtő szintű koncepció fejlesztéséhez létrehozták a hatévente ismétlődő Joint Danube Survey-t (JDS), vagyis a Közös Duna Felmérést.

\subsection{A Közös Duna Felmérés}

2001-ben, 2007-ben, 2013-ban és 2019-ben történt meg. A Duna és annak állapotát befolyásoló jelentős mellékvízfolyások hatásának egy pillanatképét adja, az ismétlődésekkel pedig a változások tendenciáját lehet nyomon követni.

A 2015-ben készült felmérés alapján megállapították, hogy a felszíni vizek minősége javuló tendenciát mutat, de számos mellékfolyón és a Duna alsóbb szakaszain a városok közelében a tápanyag-feldúsulás jellemzi, illetve a veszélyesanyag-terhelések kockázata is nő.

A JDS egy önálló és komplex nagyfolyófelmérés, amelynek célja, hogy a vízminőségmérés egy folyamatos fejlődési tendenciát mutasson mind technikai, mind pedig adatpótlási szempontból. Feladata a meglévő rendszerek összehangolása, az újonnan megjelenő kémiai vegyületek vagy ezeknek a különböző hatásvonalának a feltárása, illetve az ehhez szükséges új eszközök kifejlesztése. Az ICPDR saját vezénylésü összehangolt vizsgálatai mellett minden Duna Régiós ország saját felmérést is készít. Ezeket a felkéréseket az European Environmental Agency (EEA) összesíti minden évben.

\subsection{A Duna vízgyüjtőjének baleseti kockázati pontjai és előrejelző rendszere (Accidental Early Warning System - balesetvészjelzö rendszer)}

Ha bizonyos veszélyes anyagok átlépik a meghatározott maximális küszöbértéket vagy határon átterjedő vízszennyezés kockázata áll fenn, aktiválódik a veszélyhelyzeti figyelmeztető rendszer. A rendszer figyelmeztető üzeneteket küld az alvízi országoknak, hogy segítse a hatóságokat a környezetvédelmi és közbiztonsági intézkedésekre való azonnali reagálásban.

A 2000-ben történt ciánkatasztrófa eseményei élesben tesztelték a rendszert. A romániai Zazár település közelében müködő ülepítő gátja 2000. január 30-án éjszaka egy körülbelül 25 m-es szakaszon átszakadt. A cianidot és nehézfémeket tartalmazó víz a Lápos folyóba zúdult, ahonnan a Szamosba, majd a Tiszába került. Mivel a bányavállalatnak nem volt kárelhárítási terve, a szennyezés lokalizálását vagy enyhítését meg sem kísérelték.

A szennyezőanyag koncentrációja a katasztrófa helyén a magyarországi szabvány szerinti határérték 180-szorosát is meghaladta, a Szamos és a Tisza összefolyásánál a határérték 135-szöröse volt. A duzzasztásnak és az áradásoknak köszönhető folyamatos felhígulás nyomán a Tisza-tónál 34-szeres, Szeged alatt 15-szörös volt a határérték-túllépés, de még Belgrád magasságában is okozott halpusztulást a szennyezés, amely még a Duna bulgáriai szakaszán 
is határérték feletti volt. ${ }^{16} \mathrm{~A}$ rendszer lehetővé tette azoknak az intézkedéseknek az időben történő aktiválását, amelyek megakadályozták az emberek és az ökoszisztémák még szélesebb körü károsodását a Tisza folyó mentén.

Az AEWS az egyes részt vevő országok fő nemzetközi riasztási központjainak hálózatán müködik. Ezek a központok három alapegységböl állnak: Kommunikációs egység (a nap 24 órájában müködik), amely figyelmeztető üzeneteket küld és fogad. A szakértői egység, amely a veszélyes anyagok adatbázisának és a Duna-medence riasztási modelljének felhasználásával értékeli bármely baleset lehetséges határokon átnyúló hatásait. A döntési egység, amely eldönti, hogy mikor kell nemzetközi figyelmeztetéseket küldeni.

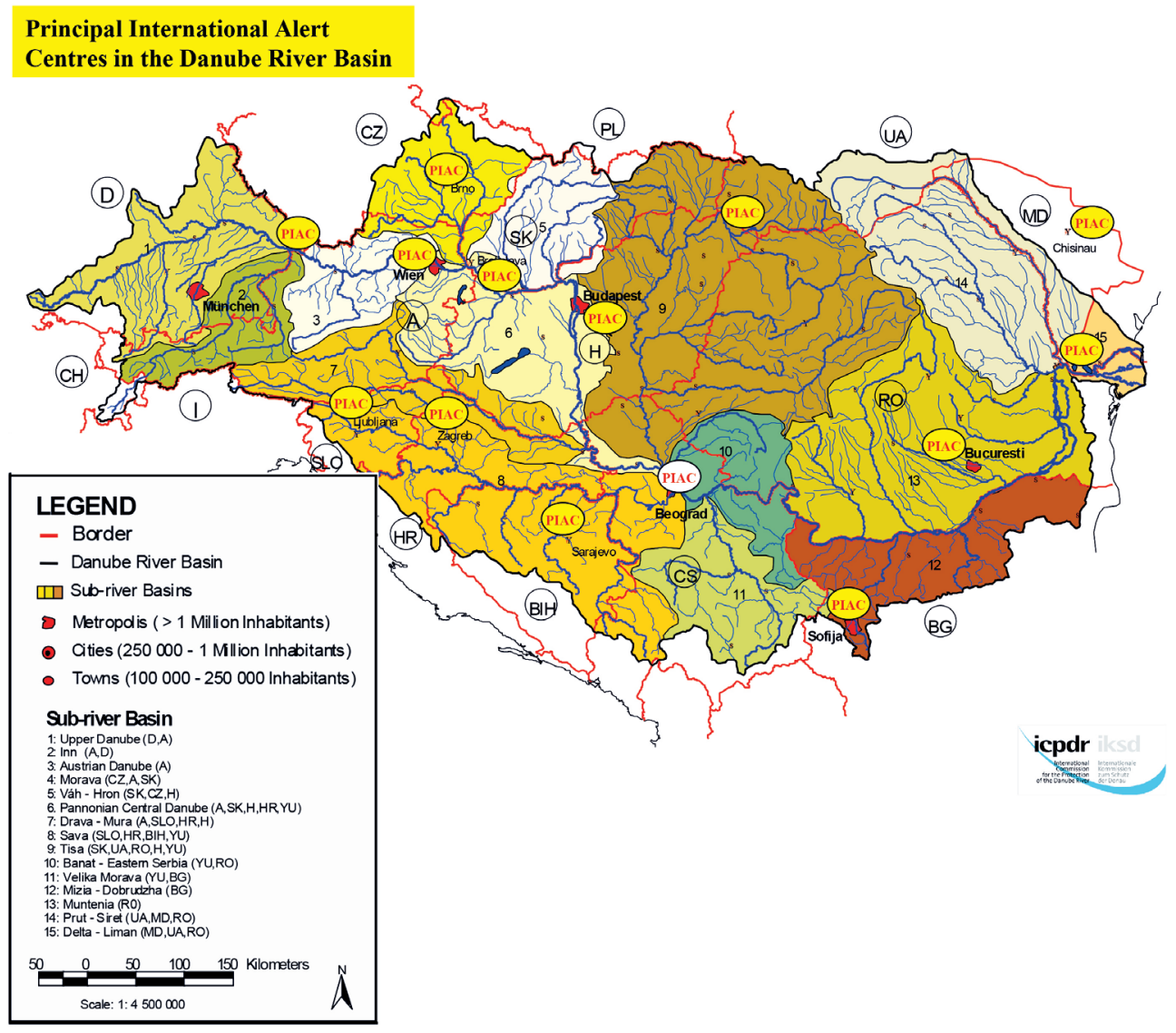

3. ábra. Elsődleges nemzetközi riasztási központok a Duna vízgyüjtöjén

Forrás: AEWS - Accident Emergency Warning System. ICPDR.

16 Tiszai cianidszennyezés. Wikipédia. 
Az AEWS első szakasza 1997 áprilisában lépett müködésbe Ausztriában, Bulgáriában, Csehországban, Horvátországban, Németországban, Magyarországon, Romániában, Szlovákiában és Szlovéniában. Ukrajna és Moldova 1999-ben lépett be a rendszerbe; valamint Bosznia és Hercegovina és a Szerb Köztársaság 2005 óta vannak a fedélzeten. A 3. ábrán láthatók ezek a riasztási központok a Duna vízgyüjtőjén.

\subsection{Baleseti szennyezés}

A Duna medencéjében bekövetkező véletlen szennyezések komoly károkkal fenyegetik a környezetüket, a helyiek egészségét. Ezt példázta 2000-ben a romániai nagybányai cianidkiömlés vagy a 2010-es, Ajkánál bekövetkezett magyarországi vörösiszap-katasztrófa. Az ICPDR a véletlenszerű szennyezés megelőzésén és a reagálási képességek javításán dolgozik az összes releváns baleseti kockázat jegyzékének összeállításával (3. ábra).

A baleseti kockázati foltok leltára magában foglalja az üzemi ipari helyszíneket, amelyek az üzemekben előállított, tárolt vagy felhasznált vegyi anyagok jellege miatt jelentős baleseti szennyezéssel járnak, valamint szennyezett helyek, ideértve a hulladéklerakókat és az áradásnak kitett területek hulladéklerakóit is. A 4. ábrán láthatók a területek, amelyek leltárát 2001-ben véglegesítették a Duna legtöbb országában, és 2003-ban aktualizálták. Az árvízveszélyes területeken található szennyezett területek leltározása előkészítés alatt áll.

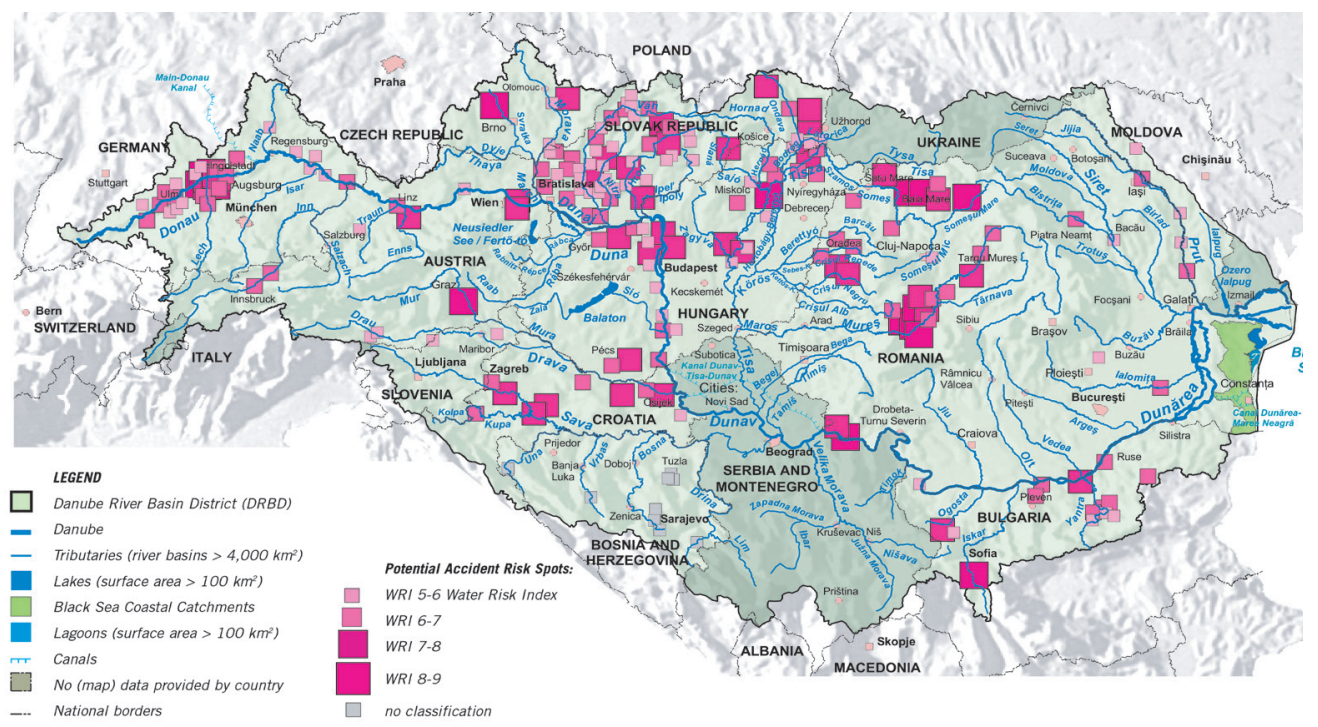

4. ábra. Az ICPDR-jelentésben szereplő potenciális kockázati (ARS) pontok a Duna vízgyűjtőjén

Forrás: Danube River Basin District. Potential Accident Risk Spots. 2005. június. 


\section{A Duna Régió Stratégia (European Union Strategy for the Danube Region - EUSDR)}

A szervezet nevéből is adódóan a stratégiai szintet képviseli. Az ICPDR és az EUSDR összehangolja tevékenységét a szinergiák kihasználása érdekében. Az EUSDR cselekvési terve konkrét intézkedéseket és projektpéldákat határoz meg 11 tematikus prioritási területen (Priority Area), azzal a céllal, hogy kezelje a régió közös kihívásait.

A 4. prioritási területe (PA4) „A vizek minőségének fenntartásával és helyreállításával és az európai vízkészletek védelmével" foglalkozik. Feladata az EU vízügyi keretirányelvének (WFD) és a települési szennyvíz kezeléséről szóló irányelv (UWWTD) végrehajtásának támogatása, a halmigráció és a mezőgazdasági szennyezés elleni intézkedések támogatása.

\section{A hazai felszíni vizek VKI szerinti megfigyelésének müködése}

A Víz Keretirányelv (2000/60/EK; VKI) V. melléklete meghatározza a víztestek állapotának értékeléséhez szükséges vizsgálatok körét, a minimális vizsgálati gyakoriságot és az értékelési módszer alapjait. A monitoringprogram részletes kidolgozása a tagállamok feladata. A VKI célkitüzéseinek elérése és az ehhez szükséges adatok az alapjai az állapotértékelésének.

Jelenleg hazánkban háromszintű monitoringrendszer alapján értékelik a víztesteket, a nemzetközi (ICPDR-) minta alapján. Az alapmonitoring (feltáró), amely biztosítja a hatévente jelentendő Vízgyűjtő Gazdálkodási Terv ciklus monitoringprogramjához szükséges hosszú távú adatsorokat. Az alapmonitoring vizsgálati pontjai egyesítenek egyéb mérési igényeket, mint például határvízi megállapodások, védett területek monitoringja, nitrátérzékeny területek monitoringjának legnagyobb része. A klasszikus vizsgálati paraméterek szerint évi 12 minta a jellemző, a biológiai vizsgálatok élőlénycsoportonként eltérő gyakorisággal történnek, a veszélyes anyagokat háromévenként egyszeri gyakorisággal mérik. A természetes medermorfológiai vizsgálatokat az emberi beavatkozások hatásának lassú kimenetele miatt szintén hatévente monitorozzák. A határral osztott víztestek esetében a megfigyelési adatokat kétoldalú határvízi szerződések vagy együttműködés alapján megosztják a szomszédos országokkal. A Duna-medence szintjén kiemelt víztestek esetében a feltáró monitoringból származó információkat az ICPDR-en keresztül a többi dunai országnak is meg kell küldeni. A feltáró monitoringhoz kapcsolódó program keretében történik az interkalibrációs hálózat müködtetése, valamint a referenciahelyek vizsgálata is. A 2005/646/EK Bizottsági Határozat (interkalibrációs hálózatot alkotó helyek nyilvántartásának létrehozásáról) részeként 16 vízfolyás és öt állóvíz-monitoringpontot üzemeltet csekély mértékü zavarásnak kitett állapotot tükröző referenciahelyeken. ${ }^{17}$

Az úgynevezett operatív monitoringgal a bizonyos szempontból veszélyesnek tekintett vagy változtatásnak kitett vizek vizsgálata történik. Ennek a keretében nyolc alprogramot hoztak létre, két programot az állóvizekre, és hat programot a vízfolyásokra. A veszélyeztetett víztesteket

17 Európai Bizottság: A Bizottság jelentése az európai parlamentnek és a tanácsnak a vízpolitikai keretirányelvben (2000/60/EK) előirt vízgyüjtő-gazdálkodási tervek végrehajtásáról. Brüsszel, 2012. 
érintő monitoringhelyszíneket különböző hatások vizsgálatára választották ki. A különböző operatív monitoring-alprogramokhoz a biológiai minőségi elemek kiválasztására a rendelkezésre álló biológiai monitoringadatok és az egyes biológiai minőségi elemek stresszor-válasz kapcsolata alapján került sor. A VGT2 időszakában 1279 monitoringponton 863 víztesten történt mérés. Ez a 1078 víztest $80,1 \%$-ot fed le. ${ }^{18}$

A felszíni vizek monitoringfeladatait a felszíni vizek megfigyelésének és állapotértékelésének egyes szabályairól szóló 31/2004. (XII. 31.) KvVM rendelet rögzíti. ${ }^{19}$ Vizsgálati monitoringot az olyan ismerethiány pótlására végeznek, amely határértékek túllépésére reagál, olyan helyeken ahol operatív monitoring nem üzemel, vagy valamilyen intézkedési programot alakítanak ki. ${ }^{20} \mathrm{~A}$ VKI által meghatározott mind a 33 elsőbbségi anyagot megfigyelik. A veszélyes anyag miatt kockázatos folyók alprogramja 81 víztestre, illetve 103 monitoringpontra vonatkozik. E vizsgálatok keretében az elsőbbségi, illetve az egyéb veszélyes anyagok közül csak azt vizsgálják, amelyre más felmérési program határérték-túllépést mutatott, illetve amely anyagot kibocsátanak a vízgyüjtőn.

A vízgyüjtő alegységek területén történő környezeti káreseményeket ki kell vizsgálni. A komolyabb események kapcsán kárelhárítás és vizsgálati monitoring működtetése szükséges. A vizsgálati monitoring müködtetői balesetszerü szennyezés esetében a kárt okozó környezethasználó és/vagy egymással együttmüködve a környezetvédelmi, a természetvédelmi és a vízügyi államigazgatási szervek.

A védett területek monitoringja a felszíni vizekre vonatkozóan külön programként müködik a fürdővizek, a Natura2000 területek, az ivóvízkivételek védőterületein, az őshonos halak életfeltételeinek biztosítása céljából a védett területeken, valamint a nitrátszennyezésről szóló irányelv és a települési szennyvizek kezeléséröl szóló irányelv alapján kijelölt területeken. Az ilyen külön felszíni vízi monitoringhelyek teljes száma 407. Az ivóvízkivételek védőterületein a felszín alatti vizekre vonatkozó külön monitoringprogram 1754 helyet foglal magában.

\section{Felszíni vizek monitoringjának fejlesztésére irányuló nemzetközi projektek}

\subsection{Danube Hazard projekt}

A veszélyes anyagok szennyezésének kezelése a Duna-medencében méréssel, modellezésen alapuló kezeléssel és kapacitásépítéssel történik. ${ }^{21}$

Az EU vízügyi keretirányelve szerint a veszélyes anyagok szennyezése a vízminőség egyik fő problémája, amelyet a Duna-medencében meg kell oldani. Ez vonatkozik az EU-n kívüli tagállamokra is, amelyek elkötelezték magukat hasonló célok elérése mellett a Duna-védelem Nem-

18 Kovács Zsófia: Vízgyüjtőspecifikus folyamatos monitoring rendszer módszertani kidolgozása és vízminőségi osztályozó algoritmus adaptálása és tesztelése felszíni vizekre. Doktori értekezés. Pannon Egyetem, 2018.

19 31/2004. (XII. 31.) KvVM rendelet a felszíni vizek megfigyelésének és állapotértékelésének egyes szabályairól.

20 VKI Monitoring. Alsó-Duna-völgyi Vízügyi lgazgatóság, 2019.

21 Danube Hazard M3C. Danube Transnational Program. 
zetközi Bizottságában (ICPDR). A nemzeti vízgyűjtőgazdálkodási tervekben, többnyire a tudás jelentős hiányosságainak, a rendszerszintű ismeretek hiányának, valamint a HS-kibocsátási útvonalak és a hatékony kezelési lehetőségek intézményi kapacitásának hiánya miatt kiemelten fontos a nemzetközi összefogás projektszinten is. Célja a tartós és hatékony transznacionális ellenőrzés és a veszélyesanyag-szennyezés csökkentése, illetve hogy fokozza az ismereteket a szennyezés útvonalairól a Duna vízgyűjtőjében a magas koncentráció szintjére vonatkozó adatok integrálásával és összehangolásával, valamint a kísérleti régiók vízgyűjtőszintű kibocsátásának modellezésével. Részt vevő partnerek: Ausztria, Románia, Magyarország.

\subsection{SIMONA (Sediment-quality Information, Monitoring and Assessment System) projekt $^{22}$}

A Közös Duna Felmérése az üledék minőségének jellemzése érdekében mért vizsgálati eredmények komoly szennyezési értékeket mutattak. A Duna Régió tagországai azonban nem rendelkeznek elegendő intézményi kapacitással (információk, iránymutatások és módszerek) a hordalékmonitoring-hálózat kiterjesztéséhez. A projekt célja a felszíni vizeink hordalékminőségének hatékony és összehasonlítható mérésére és értékelésére irányuló jelenlegi igényre egy telepítésre kész üledékminőség-mérő információs, nyomonkövetési és értékelési rendszer biztosításával a transznacionális együttműködés támogatására. Részt vevő partnerek: Szlovénia, Bulgária, Ausztria, Magyarország.

\subsection{Tidy Up projekt ${ }^{23}$}

A Tisza-Duna integrált cselekvési terv a folyók mủanyagszennyezésének felszámolására. Az EU fejlett hulladékgazdálkodási és ambiciózus újrahasznosítási célkitűzései ellenére a tanulmányok rámutattak a makroplasztikus és mikroplasztikus szennyezés jelenlétére az európai folyókban. A Tidy Up projekt a vízminőség javítására és a mủanyagszennyezés csökkentésére összpontosít Európa egyik legsúlyosabban szennyezett folyójában, a Tiszában, és vizsgálja a műanyagszennyezést és annak hatását a Dunára és a Fekete-tengerre. Jelenleg nem állnak rendelkezésre olyan szabványos módszerek és következetes adatok a Duna-medence folyók műanyagszennyezéséröl, amelyek elősegítenék a vízgazdálkodási hatóságok összehangolt fellépését, és lehetővé tennék az együttműködést más ágazatokkal. A projektben részt vevő partnerek: Magyarország, Bulgária, Románia, Ausztria.

\section{9. Összefoglalás, következtetések}

A hazai felszíni vizek megfigyelése az 1950-es évektől folyamatosan fejlődött, mind a mintavételi helyszínek mind a mérések számának növekedésével. Ez a jelentősebb vízfolyásokat és állóvi-

22 Simona project: Danube Transnational Program.

23 Tidy Up: Danube Transnational Program. 
zeket fedte le, amivel az európai országok közül is kiemelkedik. A mérési helyszíneket illetően ugyanakkor messze alulreprezentáltak voltak a kis (1000 km²-nél kisebb vízgyűjtőterületü, 1 m³/s-nál kisebb középvízhozamú) vízfolyások.

A környezeti monitoringok országos éves jelentéseit is közzétevő Európai Környezeti Ügynökség (EEA) riportjai kimutatták az európai felszíni vizek állapota az 1980-as évek óta nem javul a meghozott intézkedések ellenére sem. Az 1990-es években ezért kidolgozták az Európai Közösség új vízpolitikáját, a Víz Keretirányelvet, amely az eddigi legnagyobb horderejű változást hozta, habár ezt megelőzően is számos Dunai együttmüködés jött létre a vizek hatékony védelme érdekében. Európai szintű közös stratégiát dolgoztak ki, amely tartalmazza a végrehajtáshoz szükséges módszertani előkészítéseket és útmutatókat. Az útmutatókat 15 európai minta-vízgyüjtőterületen tesztelték is. A VKI hazai végrehajtása a Vízgyüjtőgazdálkodási Terv elkészítésével történik, amelyet hatévente vizsgálnak felül.

Az Európai végrehajtást egy 2001-ben létrehozott szakértő csoport segíti azóta is, a Duna-védelmi Bizottság (ICPDR). A bizottság műveleteit két csoport irányítja: a rendszeresen tanácskozó munkacsoport, amely meghatározza a politikát és stratégiát, míg a felállított különleges munkacsoportok útmutatási keretet biztosítanak és előkészítik a kulcsfontosságú döntéseket.

\subsection{A monitoring hálózatának legfontosabb elemei}

A Nemzetközi Monitoringhálózat, amely folyamatosan figyeli a szennyeződéseket és az általános állapotot, évente jelent. A Közös Duna-felmérés, amelyet hatévente végeznek a Duna teljes szakaszán egy expedíciós hajóval, illetve a Duna Vízgyűjtő Baleset-vészjelző rendszere, amely baleset esetén azonnal riaszt, ha bizonyos veszélyes anyagok átlépik a meghatározott maximális küszöbértéket. A VKI hazai végrehajtásához működtetett monitoringrendszer a külföldi minta alapján három típusú vizsgálatot különböztet meg: Az alapmonitoring a hosszú távú adatsorokat biztosítja a VGT-hez. Az operatív monitoring a veszélyeztetett vizeket figyeli, a vizsgálati monitoring pedig a határértékek túllépésére reagál.

A vizek jó állapotának elősegítését és a fenntartható, integrált vízgazdálkodást elősegítő megfigyelő rendszerek folyamatos fejlődés alatt állnak, hála a vízügyi szakembereknek és az egyre nagyobb tudáshálózatot müködtető hazai és nemzetközi vízügyi szakmai fórumoknak. A fejlesztés további támogatására létrehozott projektek és azok eredményeinek reprodukálása és jó példáinak elterjedése pozitív jövőképet enged sejteni.

Az ipari, gazdasági és lakossági forrásból eredeztethető szennyező anyagok fejlődő megfigyelése ellenére a káros hatások még mindig fennállnak. Szinte naponta jelennek meg új típusú károsítók is, amelyek miatt további gyakorlati kérdések merülnek fel. Az előrejelző és reagáló apparátusok állandó fejlődése, vagyis a szennyezési helyzethez való alkalmazkodás előremutató, azonban a fenntartható környezethasználat másik fontos alappillére a mitigáció, vagyis a károsanyag-kibocsátás csökkentési intézkedések még hagynak kívánni valót maguk után. A szabályzások létrehozása után ezek betartatása az egyik legnagyobb kihívás. A károsanyag-kibocsátás megelőzése pedig szintén a társadalmi felelősségvállalás sarokpontja, amit ez esetben szívesen aposztrofálnék ipari és gazdasági felelősségvállalásként. 
A víz minősége megőrzésének egyik feltétele például az ökológiai vízigény is. Csak a megfelelő mennyiségű vízzel képes ugyanis az öntisztulásra. Az éghajlatváltozásra reagáló alkalmazkodási intézkedések, a vízmennyiséget és az éves vízmérlegdeficit kiegyenlítését támogatni hivatott természetes vízmegtartást célzó intézkedések hatásainak megfigyelése új kutatási iránya a felszíni és a felszín alatti monitoringhálózatoknak.

\section{Felhasznált irodalom}

31/2004. (XII. 31.) KvVM rendelet a felszíni vizek megfigyelésének és állapotértékelésének egyes szabályairól. Online: https://net.jogtar.hu/jogszabaly?docid=a0400031.kvv

A bizottság jelentése az Európai Parlamentnek és a Tanácsnak a víz-keretirányelv (2000/60/EK) és az árvízvédelmi irányelv (2007/60/EK) végrehajtásáról. Második vízgyűjtő-gazdálkodási tervek. Első árvízkockázat-kezelési tervek. Brüsszel, 2019. Online: https://eur-lex.europa.eu/legal-content/ HU/TXT/HTML/?uri=COM:2019:95:FIN\&from=EN

A Duna-vízgyüjtö magyarországi része. Vizgyüjtö-gazdálkodási Terv - 2015. Országos Vízügyi Főigazgatóság, 2016. Online: www.vizugy.hu/vizstrategia/documents/E3E737A3-3EBC-4B6F-973C-5DD9B8A6DBAB/OVGT_foanyag_vegleges.pdf

A Víz Keretirányelv Közös Végrehajtási Stratégiája: WFD Common Implementation Strategy - Progress and Work Programme 2003/2004. Online: https://ec.europa.eu/environment/water/water-framework/objectives/pdf/strategy2.pdf

AEWS - Accident Emergency Warning System. ICPDR. Online: Az EU viz-keretirányelve. Online: https:// doi.org/10.2779/50903

Clement Adrienne - Somlyódy László: Vízminőség és sza bályozása. In Somlyódy László (szerk.): A hazai vízgazdálkodás stratégiai kérdései. Budapest, Magyar Tudományos Akadémia, 2002. 139-176. Online: http://old.mta.hu/data/Strategiai_konyvek/viz/viz_net.pdf

Common Implementation Strategyfor the Water Framework Directive (2000/60/EC). Luxembourg, Office for Official Publications of the European Communities, 2009. Online: https://circabc.europa.eu/ sd/a/ff303ad4-8783-43d3-989a-55b65ca03afc/Guidance_document_N\%C2\%B018.pdf

Danube Hazard M3C. Danube Transnational Program. Online: www.interreg-danube.eu/approved-projects/danube-hazard-m3c

Danube Rectors' Conference. Dunai Rektorok Konferenciája. Online: www.drc-danube.org/about-1/

Danube River Basin District. Potential Accident Risk Spots. 2005. június. Online: www.icpdr.org/main/ sites/default/files/Map08_Potential_Accident_Risk_Spots.pdf

EEA: A vizek állapota Európában. EEA briefing, (2003), 1. Európai Környezetvédelmi Ügynökség. Online: www.eea.europa.eu/hu/publications/briefing_2003_1

Európai Bizottság: A Bizottság jelentése az európai parlamentnek és a tanácsnak a vízpolitikai keretirányelvben (2000/60/EK) elöirt vízgyüjtö-gazdálkodási tervek végrehajtásáról. Brüsszel, 2012. Online: https://ec.europa.eu/environment/water/water-framework/pdf/3rd_report/CWD-2012-379_ENVol15_HU_hu.pdf

Hardi Tamás: Duna-stratégia és területi fejlődés. Digitális kiadás. Budapest, Akadémiai Kiadó, 2016. Online: https://doi.org/10.15 56/9789630598064

ICPDR. Duna-védelmi Bizottság. Online: www.icpdr.org/main/

Kovács Zsófia: Vízgyüjtöspecifikus folyamatos monitoring rendszer módszertani kidolgozása és vízminöségi osztályozó algoritmus adaptálása és tesztelése felszíni vizekre. Doktori értekezés. Pannon Egyetem, 2018. Online: https://doi.org/10.18136/PE.2018.676 
Nagy Zsuzsanna: A biológiai elemek állapotát befolyásoló föbb hidromorfológiai tényezők meghatározása magyarországi kisvizfolyásokra. Doktori értekezés. Budapest, Corvinus Egyetem, Kertészettudományi Doktori Iskola, 2007. Online: http://phd.lib.uni-corvinus.hu/282/1/nagy_zsuzsanna.pdf

Simona project: Danube Transnational Program. Online: www.interreg-danube.eu/approved-projects/ simona

Somlyódy László: Felszíni vizek minősége. Budapest, Typotex, 2018.

Somlyódy László: Vízminőségi modellek és a mérnök. Hidrológiai Közlöny, 98. (2018), 2. 13-22. Online: https://library.hungaricana.hu/hu/view/HidrologiaiKozlony_2018/?pg=88\&layout=s

Szabó Attila Péter: Háttérváltozók szerepe a Duna és a Tisza ökológiai minősitésében. Doktori értekezés. Debreceni Egyetem, 2008. Online: https://dea.lib.unideb.hu/dea/bitstream/handle/2437/89761/ ertekezes. . df? sequence=4\&isAllowed $=y$

Tidy Up: Danube Transnational Program. Online: www.interreg-danube.eu/approved-projects/tid-y-up Tiszai cianidszennyezés. Wikipédia. Online: https://hu.wikipedia.org/wiki/Tiszai_cianidszennyez\%C3\%A9s VKI Monitoring. Alsó-Duna-völgyi Vízügyi lgazgatóság, 2019. Online: www.aduvizig.hu/vki-monitoring/ www.icpdr.org/main/activities-projects/aews-accident-emergency-warning-system 